\title{
Effects of feeding diets composed of corn silage and a corn milling product with and without supplemental lysine and methionine to dairy cows
}

\author{
W. P. Weiss* \\ Department of Animal Sciences, Ohio Agricultural Research and Development Center, The Ohio State University, Wooster 44691
}

\begin{abstract}
Formulating diets with high inclusion rates of a feed that provides necessary nutrients at lower-thanmarket prices for those nutrients should increase income over feed costs if the feed is not detrimental to yields of milk and milk components. The objective of this study was to determine whether cows fed a diet composed of approximately $53 \%$ corn silage, $44 \%$ corn milling product $(68 \%$ dry matter, $21 \%$ crude protein, $37 \%$ neutral detergent fiber, and 9\% starch) and $3 \%$ minerals (CMP) would have similar productivity as cows fed a control diet of predominantly corn silage, alfalfa silage, corn grain, and soybean meal. Based on the National Research Council (2001) dairy model, the CMP diet was inadequate in metabolizable methionine and extremely low in metabolizable lysine. A third treatment $(\mathrm{CMP}+\mathrm{AA})$ was the same as the CMP diet but was supplemented with rumen-protected lysine and methionine. Twenty-one Holstein cows were used in a replicated Latin square (28-d periods) design to evaluate production responses to the 3 diets. Diets were formulated to contain the same concentration of net energy for lactation and metabolizable protein (MP) based on the National Research Council model, but diets with CMP contained more neutral detergent fiber (38.3 vs. $31.4 \%)$ and less starch (21.6 vs. $30.5 \%)$ than the control diet. Lysine as a percent of MP was 6.5, 6.0, and 6.8 for the control, CMP, and CMP+AA diets, respectively, and methionine was $1.8,1.8$, and $2.3 \%$ of MP, respectively. Dry matter intake was not affected by diet $(24.3 \mathrm{~kg} / \mathrm{d})$, but milk yield was lower for cows fed either CMP diet than for those fed control (36.0 vs $38.1 \mathrm{~kg} / \mathrm{d}$ ). Milk fat concentrations were normal and not affected by diet $(3.7 \%)$. Milk protein concentration was greater for cows fed $\mathrm{CMP}+\mathrm{AA}$ than for cows fed the other 2 treatments (3.19 vs. $3.11 \%$ ); however, milk protein yield was greatest for cows fed the conventional diet. The concentration of methionine in plasma was significantly greater for cows fed $\mathrm{CMP}+\mathrm{AA}$ than for
\end{abstract}

Received August 10, 2018.

Accepted November 8, 2018.

*Corresponding author: weiss.6@osu.edu cows fed the other diets. Plasma lysine concentrations were greater for cows fed the conventional diet than for those fed the other 2 diets. Plasma concentrations of several essential AA were lower for cows fed either CMP diet. Based on calculated energy balance, diets contained similar concentrations of net energy for lactation, but cows fed CMP diets partitioned more energy toward body energy reserves than did control cows, perhaps because supply of specific AA limited milk synthesis.

Key words: nonforage fiber source, corn gluten feed, lysine, methionine

\section{INTRODUCTION}

One method of reducing feed costs is to use high inclusions rates of ingredients that have lower-thanaverage nutrient costs. This approach could result in a TMR having very few ingredients. Reducing the number of ingredients added to a ration on the farm reduces inventory needs and the time required to make the TMR, but diets based on only a few ingredients can increase risk. If a feed with a high inclusion does not contain the expected concentration of a specific nutrient, the total diet will be substantially different from formulation specifications, and because concentration of $\mathrm{NE}_{\mathrm{L}}$ and $\mathrm{MP}$ are estimated, errors for individual feeds can be high. Diets based on a few ingredients may also be inadequate in poorly defined nutrients, such as specific AA, whereas a diet with a variety of ingredients may provide a more balanced set of nutrients.

Corn gluten feed and similar corn milling products $(\mathbf{C M P})$ are often an economical source of $\mathrm{NE}_{\mathrm{L}}$ and $\mathrm{MP}$ and have been fed to dairy cows at high inclusion rates. Compared with cows fed diets with no or low inclusion rates of CMP, cows fed diets with high inclusions rates have had higher (Boddugari et al., 2001), equal (Fellner and Belyea, 1991; Rezac et al., 2012; Weiss, 2012) or lower (Schroeder, 2003) milk yields; greater (Boddugari et al., 2001) or lower (Rezac et al., 2012; Weiss, 2012) feed efficiency (ECM/DMI); and greater (Schroeder, 2003) or lower (Fellner and Belyea, 1991; Boddugari et al., 2001; Rezac et al., 2012; Weiss, 2012) milk fat percentage. However, in most studies evaluat- 
ing high inclusion rates of CMP, they were included as a component of complex diets with multiple forages and concentrates. One experiment conducted by Boddugari et al. (2001) compared a multi-ingredient complex diet to a diet containing only alfalfa silage, corn silage, and CMP (plus minerals and vitamins), and cows fed the simpler diet produced milk with lower protein concentration but had greater feed efficiency (FCM/DMI). One potential problem with diets with high inclusions of corn gluten feed or CMP is a poor AA balance, especially Lys (NRC, 2001). We hypothesized that a diet based solely on corn silage and CMP (plus minerals and vitamins) would be deficient in metabolizable Lys and Met, but when those nutrients were added cows would produce similar amounts of milk and milk components as when a more conventional, multi-ingredient diet.

\section{MATERIALS AND METHODS}

\section{Cows and Diets}

Twenty-one Holstein cows were used in 7 replicated $3 \times 3$ Latin squares with 28 -d periods. Three pairs of squares (i.e., 6 squares) were orthogonally balanced. Cows were divided into 7 blocks (i.e., squares) of 3 cows based on parity ( 2 blocks of first-lactation cows and 5 blocks of multiparous cows). Within square, cows were randomly assigned to a treatment sequence. All cows were between 91 and 135 DIM at the start of the experiment. Cows were moved to tiestalls and fed a preliminary diet for $7 \mathrm{~d}$ to acclimate to the stalls. The diet was a 60:40 blend (DM basis) of the control diet and the CMP diet (Table 1); after the acclimation period, cows were abruptly changed to their appropriate treatment diet. Cows were fed a TMR once daily for ad libitum consumption (refusal averaged $4 \%$ of amount fed) and were milked twice daily with milk yield measured electronically. Amount of feed offered and orts were measured daily to calculate DMI. Cows were weighed on 2 consecutive days at the start of each period and on the last $2 \mathrm{~d}$ of period 3 . The 2 consecutive day weights were averaged to calculate change in BW over the periods. Cows were body condition scored, where $1=$ emaciated and $5=$ obese (Wildman et al., 1982), by 3 independent scorers on d 2 of each period and on the last day of period 3 .

Cows were fed 1 of 3 diets (Tables 1 and 2). The first diet (control) was predominantly corn silage, alfalfa silage, corn grain, and soybean meal and was formulated to be adequate in $\mathrm{NE}_{\mathrm{L}}$ and $\mathrm{MP}$ to support $40 \mathrm{~kg}$ of milk (NRC, 2001). The second diet contained only CMP (Table 3), corn silage, and a mineral and vitamin mix (CMP diet). Assuming the same DMI as for the control diet, this diet would provide adequate $\mathrm{NE}_{\mathrm{L}}$ and $\mathrm{MP}$ for
$40 \mathrm{~kg}$ of milk (NRC, 2001); however, this diet had less starch, more NDF, and less metabolizable Lys and Met (per NRC, 2001 model) than the control diet (Table $2)$. The third $\operatorname{diet}(\mathbf{C M P}+\mathbf{A A})$ was exactly the same as the CMP diet except $200 \mathrm{~g}$ of a mixture of $57.5 \%$ rumen-protected (RP) Lys (MetaboLys, H. J. Baker \& Bro. Inc., Westport, CT), 14\% RP Met (Smartamine M, Adisseo, Inc., Alpharetta, GA), and $28.5 \%$ wheat middling was added to the TMR each morning. The top dress replaced approximately $0.8 \%$ of TMR DM. Based on the information provided by the manufacturers, the Lys product contained $70 \%$ metabolizable Lys and the Met product contained 60\% metabolizable Met. On average (using average DMI for cows on that treatment), the supplement provided $70 \mathrm{~g} / \mathrm{d}$ of metabolizable Lys and $14 \mathrm{~g} / \mathrm{d}$ of metabolizable Met. Those amounts were chosen because they resulted in the recommended (Schwab et al., 2009) concentrations of Lys and Met as calculated by the NRC (2001) model. The top dress was added to the TMR immediately after it was delivered to the cow and mixed in by hand. The addition of the top dress (approximately $0.8 \%$ of the TMR DM) was assumed not to change the nutrient profile of diet making it equivalent to the CMP diet (except for Lys and Met), and the amount of top dress offered was included in the DMI calculations.

Table 1. Ingredient composition of experimental diets (\% of diet DM)

\begin{tabular}{|c|c|c|c|}
\hline \multirow[b]{2}{*}{ Item } & \multicolumn{3}{|c|}{ Treatment $^{1}$} \\
\hline & Control & CMP & $\mathrm{CMP}+\mathrm{AA}$ \\
\hline Corn silage & 37.0 & 53.2 & 52.7 \\
\hline Alfalfa silage & 18.0 & 0 & 0 \\
\hline Corn milling product ${ }^{2}$ & 0 & 44.0 & 43.7 \\
\hline Corn grain, ground & 24.3 & 0 & 0 \\
\hline Soybean meal, $48 \%$ CP & 13.0 & 0 & 0 \\
\hline Soyhulls & 4.9 & 0 & 0 \\
\hline Fat, animal-vegetable blend & 0.50 & 0 & 0 \\
\hline Trace mineral salt & 0.50 & 0.50 & 0.50 \\
\hline Limestone & 1.00 & 1.76 & 1.76 \\
\hline Dicalcium phosphate & 0.22 & 0 & 0 \\
\hline Magnesium oxide & 0.04 & 0 & 0 \\
\hline Vitamin/trace mineral mix $^{3}$ & 0.54 & 0.54 & 0.54 \\
\hline AA top dress ${ }^{4}$ & 0 & 0 & 0.8 \\
\hline
\end{tabular}

${ }^{1}$ Diets based on conventional ingredients (control) or corn silage and a corn milling product without (CMP) or with supplemental rumenprotected lysine and methionine (CMP+AA).

${ }^{2}$ Cargill (Blair, NE). See Table 3 for nutrient composition.

${ }^{3}$ Composed of $0.45 \%$ copper sulfate, $1.8 \%$ Zn methionine mix (Zinpro-100, Zinpro Corp., Eden Prairie, MN), 9.3\% selenium yeast (Selenosource AF600, Diamond V Mills, Cedar Rapids, IA), $2.3 \%$ vitamin A premix $(30,000 \mathrm{IU} / \mathrm{g}), 9.2 \%$ vitamin $\mathrm{D}$ premix $(3,000$ $\mathrm{IU} / \mathrm{g}), 8.3 \%$ vitamin $\mathrm{E}$ premix $(44 \mathrm{IU} / \mathrm{g})$, and $68.65 \%$ biotin premix (Biotin-100, DSM Nutritional Products, Parsippany, NJ).

${ }^{4}$ Composed of $28.5 \%$ wheat middling carrier, $14 \%$ Smartamine M (Adisseo Inc., Alpharetta, GA) and 57.5\% MetaboLys (H. J. Baker and Bro. Inc., Westport, CT) that was top-dressed at a constant 200 $\mathrm{g} / \mathrm{d}$, which based on treatment-average DMI, was equal to $0.8 \%$ of the diet. 
Table 2. Nutrient composition of diets (\% of DM)

\begin{tabular}{|c|c|c|c|}
\hline \multirow[b]{2}{*}{ Item } & \multicolumn{3}{|c|}{ Treatment $^{1}$} \\
\hline & Control & CMP & $\mathrm{CMP}+\mathrm{AA}$ \\
\hline DM & 62.0 & 52.2 & 52.2 \\
\hline $\mathrm{NE}_{\mathrm{L}}{ }^{2} \mathrm{Mcal} / \mathrm{kg}$ & 1.57 & 1.56 & 1.56 \\
\hline NDF & 31.3 & 38.3 & 38.3 \\
\hline IVNDFD ${ }^{3} \%$ of NDF & 55.0 & 61.1 & 61.1 \\
\hline Forage NDF & 23.6 & 22.2 & 22.2 \\
\hline Starch & 30.8 & 21.6 & 21.6 \\
\hline $\mathrm{CP}$ & 16.0 & 15.9 & 15.9 \\
\hline $\mathrm{RDP}^{2}$ & 9.7 & 9.5 & 9.4 \\
\hline $\mathrm{RUP}^{2}$ & 6.4 & 6.4 & 6.5 \\
\hline $\mathrm{MP}^{2}$ & 10.9 & 10.9 & 11.0 \\
\hline $\mathrm{Lys}^{2} \%$ of MP & 6.46 & 6.01 & 6.84 \\
\hline Met, ${ }^{2} \%$ of MP & 1.79 & 1.80 & 2.32 \\
\hline Total fatty acids (TFA) & 2.97 & 2.31 & 2.31 \\
\hline $\mathrm{C} 16: 0, \%$ of TFA & 15.1 & 12.0 & 12.0 \\
\hline C18: $0, \%$ of TFA & 3.3 & 2.1 & 2.1 \\
\hline $\mathrm{C} 18: 1, \%$ of $\mathrm{TFA}$ & 17.0 & 17.0 & 17.0 \\
\hline $\mathrm{C} 18: 2, \%$ of TFA & 37.6 & 44.1 & 44.1 \\
\hline $\mathrm{C} 18: 3, \%$ of $\mathrm{TFA}$ & 7.2 & 3.6 & 3.6 \\
\hline Ash & 6.5 & 7.8 & 7.8 \\
\hline $\mathrm{Ca}$ & 0.81 & 0.77 & 0.77 \\
\hline $\mathrm{P}$ & 0.35 & 0.54 & 0.54 \\
\hline $\mathrm{Mg}$ & 0.19 & 0.28 & 0.28 \\
\hline $\mathrm{K}$ & 1.28 & 1.30 & 1.30 \\
\hline
\end{tabular}

${ }^{1}$ Diets based on conventional ingredients (control) or corn silage and a corn milling product without (CMP) or with supplemental rumenprotected lysine and methionine ( $\mathrm{CMP}+\mathrm{AA})$.

${ }^{2}$ Calculated (NRC, 2001) using treatment average DMI and assayed feed composition. Protein fraction data from NRC (2001) feed library. ${ }^{3} 30$-h in vitro NDF digestibility.

\section{Sampling and Analyses}

Feeds were sampled weekly and samples were stored in the freezer $\left(-20^{\circ} \mathrm{C}\right)$ until composited by period. Subsamples of each silage were analyzed for $\mathrm{DM}\left(105^{\circ} \mathrm{C}\right.$ for $24 \mathrm{~h}$ ) weekly and the values were used to adjust as-fed inclusion rates as necessary. At the conclusion of the experiment, the composite samples were thawed, mixed, and a subsample of the silages and CMP were dried at $55^{\circ} \mathrm{C}$ for $24 \mathrm{~h}$ and then ground through a 1-mm screen (Wiley Mill, Arthur A. Thomas, Philadelphia, PA). The concentrate mix was not dried or ground before analysis. Ground samples were assayed for DM $\left(100^{\circ} \mathrm{C}\right.$ oven for $\left.24 \mathrm{~h}\right), \mathrm{NDF}$ (Ankom ${ }^{200}$ Fiber Analyzer, Ankom Technology, Fairport, NY) with sodium sulfite and amylase (Ankom \#FAA), CP (Kjeldahl $\mathrm{N} \times$ $6.25)$, ash $\left(600^{\circ} \mathrm{C}\right.$ overnight), starch (Weiss and Wyatt, 2000), and long-chain fatty acids (Weiss and Wyatt, 2003). The NDF residue was assayed for $\mathrm{N}$ as above (neutral detergent insoluble $\mathrm{CP}$ ). Silages and CMP were dry-ashed (AOAC International, 2000) and concentrates were digested with perchloric acid (AOAC International, 2000); both were assayed for minerals using an inductively coupled plasma spectrograph. Samples of silages, CMP, and the TMR (constructed from ground feed samples) were assayed for 30-h in vitro NDF digestibility (Cumberland Valley Analytical Services, Hagerstown, MD; Goering and Soest, 1970). The concentrations of RDP (based on a 16-h in situ incubation), RUP (CP remaining after 16-h in situ incubation), RUP digestibility, and digestible undegradable AA were estimated using a 3-step procedure (Calsamiglia and Stern, 1995). This consisted of incubating the dried ground TMR samples in situ for $16 \mathrm{~h}$ in a rumen of a Jersey cow fed a diet of approximately $50 \%$ corn silage, $10 \%$ alfalfa hay, and $40 \%$ of a corn grain and soybean meal concentrate (the diet did not contain CMP) and then the residue from the bags were subjected to in vitro enzymatic digestion (Calsamiglia and Stern, 1995). The dry ground TMR samples were assayed for AA composition by Agricultural Experiment Station Chemical Laboratories (Columbia, MO) by HPLC. Feed refusals were sampled once per period (during wk 3) from each cow and assayed for DM.

Milk was sampled (a.m. and p.m.) at the regular milkings on $\mathrm{d} 7,14,21$, and 28 of each period and assayed for milk fat, protein, lactose (B2000 Infrared Analyzer, Bentley Instruments, Chaska, MN), and MUN (Skalar SAN Plus segmented flow analyzer, Skalar Inc., Nor-

Table 3. Composition of the corn milling product (CMP) and silages used in the experiment (\% of DM $)^{1}$

\begin{tabular}{|c|c|c|c|c|c|c|}
\hline \multirow[b]{2}{*}{ Nutrient } & \multicolumn{2}{|c|}{ Corn silage } & \multicolumn{2}{|c|}{ Alfalfa silage } & \multicolumn{2}{|c|}{ CMP } \\
\hline & Mean & $\mathrm{SD}$ & Mean & SD & Mean & $\mathrm{SD}$ \\
\hline $\mathrm{DM}$ & 36.5 & 1.00 & 50.3 & 2.49 & 68.2 & 0.71 \\
\hline $\mathrm{CP}$ & 7.2 & 0.15 & 20.6 & 0.89 & 21.4 & 0.63 \\
\hline NDF & 41.7 & 2.13 & 45.5 & 0.43 & 36.7 & 2.82 \\
\hline NDICP, $\%$ of $\mathrm{CP}$ & 7.9 & 0.49 & 20.5 & 1.40 & 14.4 & 0.13 \\
\hline IVNDFD, $\%$ of NDF & 52.0 & 1.01 & 42.4 & 1.36 & 75.8 & 0.45 \\
\hline Starch & 32.8 & 1.14 & $\mathrm{ND}^{2}$ & - & 9.4 & 2.00 \\
\hline LCFA & 2.5 & 0.10 & 2.1 & 0.15 & 2.2 & 0.20 \\
\hline Ash & 3.7 & 0.04 & 11.6 & 0.67 & 6.9 & 0.29 \\
\hline
\end{tabular}

${ }^{1}$ Values are from 3 samples (period composites) of each ingredient. NDICP $=$ neutral detergent insoluble CP; IVNDFD $=$ in vitro NDF digestion after $30 \mathrm{~h}$ of incubation; LCFA = long-chain fatty acids.

${ }^{2}$ Not determined. 
cross, GA) by DHI Cooperative Inc. (Columbus, OH). A composited subsample of milk on those days was assayed for fatty acid profile using a 2-step procedure for methylation (Jenkins, 2000) with separation by GLC using a CP-SIL88 capillary column $(100 \mathrm{~m} \times 0.25$ $\mathrm{mm} \times 0.2 \mu \mathrm{m}$ film thickness; Varian Inc., Palo Alto, CA). A blood sample was taken from the tail vein of each cow on d 25 of each period into tubes containing EDTA. The blood was centrifuged $\left(4^{\circ} \mathrm{C}\right)$ at $2,500 \times$ $g$ for 15 min within 30 min of sampling, plasma was removed and frozen $(-20 \mathrm{C})$ until assayed for AA and urea by the Agricultural Experiment Station Chemical Laboratories (Columbia, MO) using ion exchange HPLC (Fekkes, 1996).

\section{Calculations and Statistical Analyses}

Average BW for each cow-period was used to calculate $\mathrm{NE}_{\mathrm{L}}$ used for maintenance and period-average milk component yields were used to calculate $\mathrm{NE}_{\mathrm{L}}$ used for lactation (NRC, 2001). Change in body energy reserves was calculated as daily change in $\mathrm{BW} \times 5 \mathrm{Mcal} / \mathrm{kg}$ (NRC, 2001). Total $\mathrm{NE}_{\mathrm{L}}$ use (Mcal/d) was calculated as energy used for maintenance, milk production, and BW change, and that value divided by DMI was an estimate for $\mathrm{NE}_{\mathrm{L}}$ concentration of the diet. Energycorrected milk was calculated as $0.327 \times$ milk +12.97 $\times$ milk fat $+7.21 \times$ milk protein, where all values are kilograms per day (Tyrrell and Reid, 1965).

Intake, milk production, and milk composition was averaged within cow for each week within period and those data were analyzed with PROC Mixed (SAS Institute, 2011). The model included the random effect of square (i.e., block; $6 \mathrm{df}$ ), random effect of cow within square (14 df), random effect of period (2 df), the fixed effect of diet (2 df), the fixed effect of week (repeated measure; $3 \mathrm{df}$ ), and the interaction between week and treatment $(6 \mathrm{df})$. Parity was not separated from the block effect because of the limited number of first-lactation animals and the large imbalance between th number of first-lactation and older cows. Therefore, results are applicable to mixed parities and may not be accurate for specific parity groups. The denominator degrees of freedom were adjusted using the KenwardRoger method. The AR(1) covariance structure produced the lowest Bayesian information criterion and was used for all variables. When the treatment effect was significant $(P<0.05)$, means were separated using Fisher's LSD. When the time by treatment interaction was significant $(P<0.10)$, the SLICE option of PROC Mixed was used to evaluate responses. A significant time by treatment interaction may suggest that cows require a longer time to adjust to specific treatments or that detrimental responses take longer to develop on specific treatments. For variables measured only once per period, the same model was used except time and the time interaction terms were not included.

\section{RESULTS AND DISCUSSION}

Diets were formulated to be equal in $\mathrm{NE}_{\mathrm{L}}$ concentration (NRC, 2001), but diets with CMP had lower starch concentrations and higher NDF concentrations than the control diet (Table 2). The CMP diets were formulated to have lower starch because diets with high inclusion rates of CMP or corn gluten feed often caused a reduction in milk fat percentage (Fellner and Belyea, 1991; Schroeder, 2003; Weiss, 2012). The diets were also formulated to be essentially equal in model-estimated (NRC, 2001) concentrations of RDP, RUP, and MP. Library values for protein fractions and RUP digestibility were used (protein fractions in CMP were assumed to be the same as corn gluten feed in the library). The supply of RDP was 2 to $4 \%$ less than the calculated requirement. The control and CMP diets had similar estimated concentrations of digestible Met (\% of MP) and both were lower than the recommended concentration of $2.3 \%$ (Schwab et al., 2009). The concentration of Lys (\% of MP) of the CMP diet was 12\% lower and the control diet was $5 \%$ lower than recommended concentrations. The $\mathrm{CMP}+\mathrm{AA}$ was adequate in both digestible Lys and Met.

Unlike the NRC (2001) estimates, the control and CMP diets differed markedly in concentrations of RDP (16-h disappearance of CP from in situ bag), RUP, and digestible RUP calculated using data from the 3-step assay (Table 4). That assay is not appropriate for RPAA supplements and only data for the control and CMP diets are shown. Based on that assay, the CMP diet had approximately 30\% more RDP $(P<0.05$ based on $t$-test) and $40 \%$ less RUP $(P<0.05)$ than the control diet. The concentrations of most EAA were 40 to $50 \%$ less (His was the exception) for the CMP diet than the control diet. Although values estimated using NRC (2001) and the 3-step values cannot be directly compared because they are based on different assays and the NRC values were library values, not actually measured, the 3 -step assay suggests that the diets were different in MP, which is supported by the production data (discussed below).

\section{Production Measures}

Week within period was included in the statistical model to determine whether responses over time were consistent for the 3 diets. Yield of milk and yields of many milk components (Table 5; Figure 1) had a week by treatment interaction $(P<0.05)$. Week had no ef- 
fect $(P>0.20)$ on those measures for the control diet, but responses were affected by week $(P<0.05)$ for the CMP diet. The effect of week for the CMP+AA diet depended on the dependent variable (Table 5). If wk 1 data were excluded from the analysis, all week by treatment interactions became nonsignificant $(P>$ 0.3 ; data not shown). This indicates that cows adapted quickly (within $1 \mathrm{wk}$ ) to the diets and that over a 4 -wk period, as no detrimental effects developed. Statistical inferences were the same whether data from all weeks or only the last $3 \mathrm{wk}$ were included; therefore, the data from all 4 wk are shown and discussed.

Treatment did not affect DMI; however, cows fed $\mathrm{CMP}+\mathrm{AA}$ tended $(P<0.10)$ to have greater DMI than cows fed CMP. A quantitative review (Robinson, 2010) found no effect of supplementing a combination of Lys and Met on DMI by dairy cows. However, most, if not all, the control diets reviewed (Robinson, 2010) likely had higher concentrations of Lys than did the CMP diet. Yields of milk, ECM, fat, lactose, and energy were lower $(P<0.02)$ for cows fed diets with CMP than by cows fed the control diet. Yield of protein was lowest for cows fed CMP, intermediate for $\mathrm{CMP}+\mathrm{AA}$, and highest for control cows. The lower yields of milk fat, protein, energy, and, to a lesser extent, lactose for cows fed diets with CMP was caused mostly by a reduction in milk yield, not by a change in milk composition. Milk fat percentage was not affected by diet and was about average for Holstein cows. Diets with high inclusions of corn gluten feed or CMP have reduced milk fat percent (Fellner and Belyea, 1991; Rezac et al., 2012; Weiss, 2012); however, if the ratio of starch to forage NDF was approximately 1.0, milk fat percentage was maintained (Rezac et al., 2012; Weiss, 2012). The ratio in this experiment was 0.97 .

Milk protein concentration was not different between cows fed control and the CMP diet, but it increased $(P<0.02)$ when supplemental RP-AA were fed. The increase in milk protein percentage resulted in an increase in milk protein yield over cows fed CMP $(P<0.05)$. In another experiment with a diet that contained $27 \%$ corn gluten feed, supplemental RPLys and RP-Met (different products than used in the current experiment) did not affect milk protein yield or concentrations (Mullins et al., 2013). The control diet in that study contained an estimated $6.3 \%$ Lys in the MP, whereas the CMP diet only contained $6.0 \%$ (Table 2). Supplemental RP-Met often increases milk protein concentration and yield (Patton, 2010). Fewer studies have been done with supplemental RP-Lys and, on average, milk protein responses were small and not significant (Robinson, 2010). This experiment was not designed to determine whether the response was caused by Met or Lys because both were deemed deficient in the CMP diet. The increase in milk protein percentage caused by adding RP-Lys and RP-Met to the CMP diet

Table 4. Assayed protein fractions (Calsamiglia and Stern, 1995) and AA in $\operatorname{diets}^{1}$

\begin{tabular}{|c|c|c|c|c|c|}
\hline Item & \multicolumn{2}{|c|}{ Control } & \multicolumn{2}{|c|}{$\mathrm{CMP}$} & $P$-value ${ }^{2}$ \\
\hline RDP, $\%$ of DM & 8.3 & 0.41 & 10.8 & 0.53 & $<0.02$ \\
\hline RUP digestibility, $\mathrm{g}$ of digested/g of RUP & 0.58 & 0.012 & 0.54 & 0.023 & $<0.41$ \\
\hline Digestible RUP, \% of DM & 4.5 & 0.15 & 2.6 & 0.25 & $<0.02$ \\
\hline \multicolumn{6}{|c|}{ Digestible rumen-undegradable $\mathrm{AA},{ }^{3} \mathrm{~g} / \mathrm{kg}$ of DM } \\
\hline Ala & 2.56 & 0.076 & 1.92 & 0.231 & $<0.13$ \\
\hline Arg & 2.12 & 0.136 & 1.18 & 0.134 & $<0.05$ \\
\hline Asp & 3.96 & 0.189 & 1.82 & 0.195 & $<0.01$ \\
\hline Glu & 5.98 & 0.319 & 3.68 & 0.444 & $<0.02$ \\
\hline Gly & 1.87 & 0.064 & 1.15 & 0.119 & $<0.07$ \\
\hline His & 0.89 & 0.048 & 0.68 & 0.077 & $<0.26$ \\
\hline Ile & 1.78 & 0.093 & 0.93 & 0.113 & $<0.05$ \\
\hline Tyr & 1.27 & 0.059 & 0.68 & 0.060 & $<0.06$ \\
\hline Val & 2.19 & 0.086 & 1.31 & 0.146 & $<0.05$ \\
\hline
\end{tabular}

${ }^{1}$ Diets based on conventional ingredients (control) or corn silage and a corn milling product without supplemental rumen-protected lysine and methionine (CMP). This assay is not appropriate for rumen-protected AA supplements, so the third diet was not assayed.

${ }^{2}$ Diets compared using a $t$-test.

${ }^{3}$ Digestible rumen-undegradable AA were calculated as $[\mathrm{AA}(\mathrm{g} / \mathrm{kg}$ of total diet $) \times$ digestible RUP (\% of DM)]/100. 
(0.09 percentage units or $2.9 \%$ ) was similar to the average responses reported by Patton (2010) and Robinson (2010) of 0.08 percentage units and $2.3 \%$ when only RP-Met was fed. The milk protein percentage response observed in this experiment was also similar to the average response to a combination of RP-Met and RPLys of $2.7 \%$ determined by Robinson (2010).

Milk protein yield increased only $40 \mathrm{~g} / \mathrm{d}$ with supplemental RP-AA, which is approximately $0.6 \mathrm{~g}$ of additional milk protein/g of supplemental metabolizable Lys or $2.7 \mathrm{~g} / \mathrm{g}$ of supplemental metabolizable Met. Based on a meta-analysis (Vyas and Erdman, 2009), expected milk protein responses are approximately 4 $\mathrm{g}$ of milk protein/g of supplemental metabolizable Lys and 4 to $16 \mathrm{~g}$ of milk protein/g of supplemental metabolizable Met. The low responses we observed may indicate nutrients other than Lys and Met were limiting milk protein production or that the products did not supply the expected amounts of metabolizable Lys or Met.

Cows fed the diets with CMP had approximately $21 \%$ greater $(P<0.02)$ MUN concentrations than control cows, and cows fed CMP+AA had about $6 \%$ greater $(P$ $<0.05)$ MUN than cows fed CMP. Plasma urea (Table
6) was $30 \%$ higher $(P<0.01)$ for cows fed diets with CMP. The higher MUN for cows fed diets with CMP could be caused by the lower starch concentrations, higher RDP concentrations, or both (Davidson et al., 2003; Cabrita et al., 2007; Weiss et al., 2009). Based on an equation by Weiss et al. (2009), the approximate 10 percentage unit greater starch concentration in the control diet could have decreased MUN by $1 \mathrm{mg} / \mathrm{dL}$, but the difference was between and 2 and $2.8 \mathrm{mg} / \mathrm{dL}$. Estimated RDP (Table 4) was 30\% higher for cows fed the CMP diet than the control diet, essentially mirroring the change in MUN and plasma urea. However, estimated RDP from the NRC (2001) model was essentially equal between the diets. Increased RUP (at a constant CP concentration) can also elevate MUN (Cabrita et al., 2007). If digested, RUP cannot be used for protein synthesis (tissue or milk) because a specific AA or some other nutrient is limiting, then the AA supplied by RUP will likely be oxidized or metabolized to glucose or some other $\mathrm{N}$-free compound. Based on the available measurements, the specific cause of the higher MUN for the diets with CMP could not be determined. The $6 \%$ increase in MUN for cows fed $\mathrm{CMP}+\mathrm{AA}$ compared with those fed CMP could be related to greater

Table 5. Effect of diet on production measures

\begin{tabular}{|c|c|c|c|c|c|c|c|}
\hline \multirow[b]{2}{*}{ Item } & \multicolumn{3}{|c|}{ Treatment $^{1}$} & \multirow[b]{2}{*}{ SEM } & \multicolumn{3}{|c|}{$P$-value ${ }^{2}$} \\
\hline & Control & CMP & $\mathrm{CMP}+\mathrm{AA}$ & & Trt & Wk & $\operatorname{Trt} \times \mathrm{Wk}$ \\
\hline $\mathrm{BW}, \mathrm{kg}$ & $663^{\mathrm{a}}$ & $673^{\mathrm{b}}$ & $675^{\mathrm{b}}$ & 11.2 & $<0.02$ & - & - \\
\hline BW change, $\mathrm{kg} / \mathrm{d}$ & $0.05^{\mathrm{a}}$ & $0.60^{\mathrm{b}}$ & $0.64^{\mathrm{b}}$ & 0.13 & $<0.01$ & - & - \\
\hline $\mathrm{BCS}$ & 3.04 & 3.09 & 3.07 & 0.08 & $<0.60$ & - & - \\
\hline BCS change/28 d & 0.03 & 0.14 & 0.12 & 0.04 & $<0.12$ & - & - \\
\hline DMI, $\mathrm{kg} / \mathrm{d}$ & 24.3 & 23.9 & 24.7 & 1.04 & $<0.10$ & $<0.01$ & $<0.57$ \\
\hline Milk, kg/d & $38.1^{\mathrm{a}}$ & $35.8^{\mathrm{b}}$ & $36.1^{\mathrm{b}}$ & 2.43 & $<0.01$ & $<0.01$ & $<0.01^{*}$ \\
\hline $\mathrm{ECM}, \mathrm{kg} / \mathrm{d}$ & 39.5 & 37.2 & 37.9 & 2.32 & $<0.01$ & $<0.16$ & $<0.02^{\#}$ \\
\hline Milk fat, $\%$ & 3.67 & 3.74 & 3.77 & 0.21 & $<0.45$ & $<0.23$ & $<0.16$ \\
\hline Milk fat, ${ }^{3} \mathrm{~kg} / \mathrm{d}$ & $1.39^{\mathrm{a}}$ & $1.32^{\mathrm{b}}$ & $1.34^{\mathrm{ab}}$ & 0.096 & $<0.02$ & $<0.40$ & $<0.04^{\#}$ \\
\hline Milk protein, \% & $3.12^{\mathrm{b}}$ & $3.10^{\mathrm{b}}$ & $3.19^{\mathrm{a}}$ & 0.09 & $<0.02$ & $<0.23$ & $<0.40$ \\
\hline Milk protein, ${ }^{3} \mathrm{~kg} / \mathrm{d}$ & $1.18^{\mathrm{a}}$ & $1.10^{\mathrm{c}}$ & $1.14^{\mathrm{b}}$ & 0.056 & $<0.01$ & $<0.47$ & $<0.12$ \\
\hline MUN, mg/dL & $11.9^{\mathrm{a}}$ & $14.0^{\mathrm{b}}$ & $14.8^{\mathrm{c}}$ & 0.30 & $<0.01$ & $<0.13$ & $<0.25$ \\
\hline Milk lactose, $\%$ & $4.78^{\mathrm{a}}$ & $4.67^{\mathrm{b}}$ & $4.72^{\mathrm{ab}}$ & 0.068 & $<0.05$ & $<0.30$ & $<0.21$ \\
\hline Milk lactose, ${ }^{3} \mathrm{~kg} / \mathrm{d}$ & $1.82^{\mathrm{a}}$ & $1.67^{\mathrm{b}}$ & $1.70^{\mathrm{b}}$ & 0.11 & $<0.01$ & $<0.20$ & $<0.03^{\#}$ \\
\hline Milk $\mathrm{NE}_{\mathrm{L}}, \mathrm{Mcal} / \mathrm{kg}$ & 0.70 & 0.70 & 0.71 & 0.024 & $<0.37$ & $<0.22$ & $<0.18$ \\
\hline Milk $\mathrm{NE}_{\mathrm{L}},{ }^{3} \mathrm{Mcal} / \mathrm{d}$ & $26.6^{\mathrm{a}}$ & $24.9^{\mathrm{b}}$ & $25.4^{\mathrm{b}}$ & 1.53 & $<0.01$ & $<0.34$ & $<0.03^{\#}$ \\
\hline \multicolumn{8}{|l|}{ Efficiency } \\
\hline ECM/DMI & $1.63^{\mathrm{a}}$ & $1.56^{\mathrm{b}}$ & $1.54^{\mathrm{b}}$ & 0.079 & $<0.01$ & $<0.01$ & $<0.02^{*}$ \\
\hline Milk CP/CP intake & $0.30^{\mathrm{a}}$ & $0.29^{\mathrm{b}}$ & $0.28^{\mathrm{b}}$ & 0.0083 & $<0.01$ & $<0.43$ & $<0.12$ \\
\hline
\end{tabular}

\footnotetext{
${ }^{a-c}$ Means within row with unlike superscripts differ by treatment $P$-value in the Trt column.

${ }^{1}$ Diets based on conventional ingredients (control) or corn silage and a corn milling product without (CMP) or with supplemental rumenprotected lysine and methionine $(\mathrm{CMP}+\mathrm{AA})$.

${ }^{2}$ Effect of treatment (Trt), week within period (Wk), and their interaction.

${ }^{3}$ Milk component yields were calculated as measured concentrations times milk yield on the days that milk components were actually measured, not milk yield for the entire period.

*Based on Slice option (of PROC Mixed, SAS Institute Inc., Cary, NC), week did not affect $(P>0.2)$ responses for control cows but did affect $(P<0.01)$ responses for cows fed CMP or CMP+AA. Diet did not affect response during wk $1(P>0.10)$ but was significant for wk 2,3 , and $4(P<0.05)$.

\#Based on Slice option, week did not affect $(P>0.3)$ responses for control or CMP+AA cows but did affect $(P<0.01)$ responses for CMP cows. Diet did not affect response during wk $1(P>0.10)$ but was significant for wk 2,3 , and $4(P<0.05)$.
} 
(nonsignificant) intake of N. Chen et al. (2011) also reported increased MUN when cows were fed the same RP-Met product; those authors suggested that might have been caused by tissue mobilization, but, based on BW change, that is unlikely in the current experiment (Table 5).

Milk lactose concentration was lowest for cows fed $\mathrm{CMP}$, intermediate for cows fed $\mathrm{CMP}+\mathrm{AA}$, and highest for cows fed control. The lower milk concentration of lactose could reflect reduced glucose synthesis caused by a deficiency of precursors. The CMP diets were lower in starch than the control, and starch via ruminal propionate is a precursor for gluconeogenesis. However, Rezac et al. (2012) fed diets with high inclusion rates of corn gluten feed in diets with 12 to $14 \%$ starch and found no difference in milk lactose percentage in cows fed a control diet with $21 \%$ starch. With more conventional diets, reducing starch concentrations has reduced milk
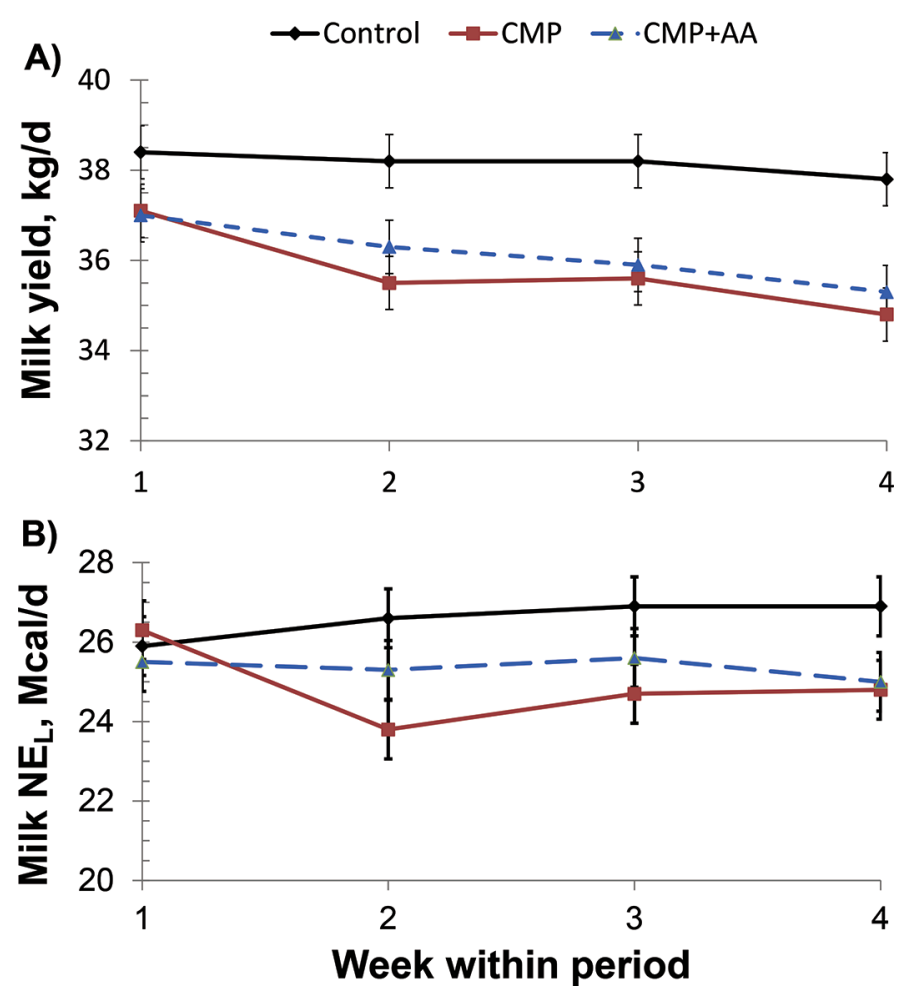

Figure 1. Milk yield (A) and milk energy output (B) by cows fed a diet based on corn silage, alfalfa silage, corn grain, and soybean meal (control; black $\bullet$ and solid line) or diets based on corn silage and a corn milling product without (CMP; red $\boldsymbol{\square}$ and solid line) and with supplemental rumen-protected Lys and Met (CMP+AA; blue $\boldsymbol{\Delta}$ and dashed line) over $4 \mathrm{wk}$ within periods of a Latin square experiment. Treatment by week interactions were observed for milk yield $(P<$ 0.01) in that week affected yield for cows fed CMP and CMP +AA but not control and for milk energy output $(P<0.05)$, which was affected by week for cows fed CMP treatment but not for those fed CMP+AA or control. For both variables, treatment had no effect during wk 1 ( $P$ $>0.10)$ but effects were noted during wk 2,3 , and $4(P<0.01)$. Error bars represent SEM. lactose concentrations (Oba and Allen, 2003), but often it has had no effect (Cabrita et al., 2007). The CMP diet had lower concentrations of most digestible AA in the RUP (Table 4) including many glucogenic AA that may have contributed to the reduced concentration of lactose. Methionine is glucogenic and may explain the higher lactose concentration for $\mathrm{CMP}+\mathrm{AA}$ treatment compared with the CMP diet. Milk energy followed the same general trend as the individual components in that its concentration was not affected by treatment, but energy output was lower for the diets with CMP than the control.

Feed efficiency (ECM/DMI) was greater for cows fed control than those fed diets with CMP (Table 5); however, this likely does not reflect energy efficiency. Cows on diets with CMP secreted less milk energy but gained more BW than cows fed the control diet. The sum of calculated energy used for maintenance, BW change, and milk was not affected by diet (Table 7), and calculated dietary $\mathrm{NE}_{\mathrm{L}}$ (energy used divided by DMI) was the same for all 3 diets. Dietary $\mathrm{NE}_{\mathrm{L}}$ calculated from energy use were essentially the same as the values calculated using the NRC (2001) model (Table 2 ). The greater BW gain and lower milk yields for cows fed CMP diets indicates that energy was not the limiting nutrient for milk synthesis. However, periods were only $28 \mathrm{~d}$, and BW change measured over a short period may not reflect longer-term changes. Based on the NRC (2001) model, $\mathrm{NE}_{\mathrm{L}}$ and $\mathrm{MP}$ were co-limiting (each had allowable milk of approximately $40 \mathrm{~kg} / \mathrm{d}$ ); however the MP-allowable milk does not consider AA profile, and data from the 3-step protein fractionation procedure (Table 4) suggest that diets with CMP had less MP than the control diet. In a previous experiment from our laboratory, in which energy intake was increased, milk yield increased only when protein intake also increased (Weiss and Pinos-Rodriguez, 2009). Protein, or more specifically AA, may have been the limiting nutrient for milk synthesis; however, lactose synthesis may also have been limiting.

\section{Plasma AA}

With the exception of Met, plasma AA concentrations did not differ between cows fed CMP and $\mathrm{CMP}+\mathrm{AA}$ (Table 6). The concentration of Met in plasma was greater $(P<0.01)$ for cows fed $\mathrm{CMP}+\mathrm{AA}$ than for those fed CMP. Cows fed the 2 diets with CMP had lower $(P<0.02)$ concentrations of total EAA, total branched-chain AA, Lys, Met (not for those fed supplemental RP-AA), Ile, Phe, Thr, and Val. The concentration of His, however, was higher for cows fed the CMP-based diets. In general, the differences in plasma EAA concentrations mimic differences found 
WEISS

Table 6. Effect of treatment on concentrations of plasma AA $(\mu \mathrm{mol} / \mathrm{L})$ and urea

\begin{tabular}{|c|c|c|c|c|c|}
\hline \multirow[b]{2}{*}{ Item } & \multicolumn{3}{|c|}{ Treatment $^{1}$} & \multirow[b]{2}{*}{ SEM } & \multirow[b]{2}{*}{$P$-value } \\
\hline & Control & CMP & $\mathrm{CMP}+\mathrm{AA}$ & & \\
\hline Lys & $63.0^{\mathrm{a}}$ & $48.6^{\mathrm{b}}$ & $49.9^{\mathrm{b}}$ & 3.03 & $<0.01$ \\
\hline Met & $17.8^{\mathrm{b}}$ & $15.7^{\mathrm{b}}$ & $33.3^{\mathrm{a}}$ & 1.42 & $<0.01$ \\
\hline Ala & $224.0^{\mathrm{a}}$ & $189.0^{\mathrm{b}}$ & $202.7^{\mathrm{b}}$ & 10.8 & $<0.03$ \\
\hline Arg & 74.6 & 68.6 & 72.3 & 5.22 & $<0.60$ \\
\hline Asn & $28.5^{\mathrm{a}}$ & $23.2^{\mathrm{b}}$ & $23.2^{\mathrm{b}}$ & 1.37 & $<0.01$ \\
\hline Asp & 7.45 & 7.89 & 8.20 & 0.67 & $<0.70$ \\
\hline Gln & 201.1 & 217.3 & 213.4 & 12.9 & $<0.07$ \\
\hline Glu & $49.9^{\mathrm{b}}$ & $58.3^{\mathrm{a}}$ & $59.8^{\mathrm{a}}$ & 2.30 & $<0.01$ \\
\hline Gly & $255.6^{\mathrm{a}}$ & $183.6^{\mathrm{b}}$ & $176.1^{\mathrm{b}}$ & 13.7 & $<0.01$ \\
\hline His & $41.2^{\mathrm{b}}$ & $46.0^{\mathrm{a}}$ & $46.8^{\mathrm{a}}$ & 2.37 & $<0.01$ \\
\hline Ile & $105.0^{\mathrm{a}}$ & $82.9^{\mathrm{b}}$ & $83.2^{\mathrm{b}}$ & 5.01 & $<0.01$ \\
\hline Leu & 115.5 & 103.3 & 105.0 & 7.63 & $<0.18$ \\
\hline Phe & 35.3 & 32.1 & 31.8 & 1.42 & $<0.06$ \\
\hline Pro & 72.6 & 70.3 & 73.7 & 3.13 & $<0.58$ \\
\hline Ser & $81.7^{\mathrm{a}}$ & $77.9^{\mathrm{ab}}$ & $73.1^{\mathrm{b}}$ & 2.76 & $<0.05$ \\
\hline Thr & $97.1^{\mathrm{a}}$ & $78.9^{\mathrm{b}}$ & $79.1^{\mathrm{b}}$ & 3.77 & $<0.01$ \\
\hline Trp & 85.1 & 80.7 & 79.0 & 3.46 & $<0.26$ \\
\hline Tyr & 38.0 & 36.1 & 36.1 & 1.95 & $<0.53$ \\
\hline Val & $216.4^{\mathrm{a}}$ & $186.6^{\mathrm{b}}$ & $187.1^{\mathrm{b}}$ & 13.0 & $<0.01$ \\
\hline EAA & $851.2^{\mathrm{a}}$ & $743.8^{\mathrm{b}}$ & $767.4^{\mathrm{b}}$ & 37.8 & $<0.02$ \\
\hline Branched-chain AA & $437.0^{\mathrm{a}}$ & $372.9^{\mathrm{b}}$ & $375.4^{\mathrm{b}}$ & 25.1 & $<0.01$ \\
\hline Urea, $\mathrm{mmol} / \mathrm{L}$ & $4.38^{\mathrm{b}}$ & $5.66^{\mathrm{a}}$ & $5.73^{\mathrm{a}}$ & 17.3 & $<0.01$ \\
\hline
\end{tabular}

${ }^{a, b}$ Means in a row with unlike superscripts differ by $P$-value in far right column.

${ }^{1}$ Diets based on conventional ingredients (control) or corn silage and a corn milling product without (CMP) or with supplemental rumen-protected lysine and methionine (CMP+AA).

in the concentrations of those $\mathrm{AA}$ in digestible RUP (Table 4). However, concentrations of Leu and Arg in digestible RUP were lower for the CMP diet, but the plasma concentrations did not differ. The lower plasma concentrations of numerous EAA of cows fed CMP may mean that multiple AA were limiting milk protein production.

The $112 \%$ increase $(P<0.01)$ in plasma Met for cows fed $\mathrm{CMP}+\mathrm{AA}$ is within the range of increases reported previously at similar supplementation rate using the same product (Rulquin and Delaby, 1997; Ordway et al., 2009). Plasma Lys responses to increases in the supply of metabolizable Lys have been variable. Studies differ in the method used to increase the supply of metabolizable Lys (feeding various protected products or infusions into the abomasal, duodenal, or systemic circulation). In studies in which increased Lys supply did not increase milk protein yield, plasma concentrations of Lys usually increased (Guinard and Rulquin, 1994; Piepenbrink et al., 1996; Varvikko et al., 1999). This could be because increased entry of Lys into the plasma pool was not countered by increased uptake by the mammary gland. However, when additional Lys (often in combination with other AA) increased milk protein yield, both increases and no changes in plasma Lys have been reported (Donkin et al., 1989; Vanhatalo et al., 1999; Appuhamy et al., 2011; Lee et al., 2012). Even within a single experiment, relationships between

Table 7. Effect of diet on calculated $\mathrm{NE}_{\mathrm{L}}$ use and feed $\mathrm{NE}_{\mathrm{L}}{ }^{1}$

\begin{tabular}{lccccc}
\hline Function $^{2}$ & Control & CMP & CMP +AA & SEM & $P$-value \\
\hline Maintenance, Mcal/d & $10.4^{\mathrm{a}}$ & $10.6^{\mathrm{b}}$ & $10.6^{\mathrm{b}}$ & 0.13 & $<0.03$ \\
Milk, Mcal/d & $26.7^{\mathrm{a}}$ & $25.1^{\mathrm{b}}$ & $25.6^{\mathrm{ab}}$ & 0.83 & $<0.01$ \\
BW change, Mcal/d & $0.3^{\mathrm{a}}$ & $3.0^{\mathrm{b}}$ & $3.2^{\mathrm{b}}$ & 0.69 & $<0.02$ \\
Total NE $_{\mathrm{L}}$ use, Mcal/d & 37.5 & 38.4 & 39.2 & 0.90 & $<0.18$ \\
Feed NE $_{\mathrm{L}}$, Mcal/kg & 1.55 & 1.62 & 1.61 & 0.037 & $<0.20$ \\
\hline
\end{tabular}

$\overline{\mathrm{a}, \mathrm{b}}$ Means in a row with unlike superscripts differ by $P$-value in far right column.

${ }^{1}$ Diets based on conventional ingredients (control) or corn silage and a corn milling product without (CMP) or with supplemental rumen-protected lysine and methionine (CMP+AA).

${ }^{2} \mathrm{NE}_{\mathrm{L}}$ used for maintenance, milk, and BW change (measured over a 28-d period) were calculated using NRC (2001) equations. The $\mathrm{NE}_{\mathrm{L}}$ for $\mathrm{BW}$ change was set at $5 \mathrm{Mcal} / \mathrm{kg}$.

${ }^{3}$ Total $\mathrm{NE}_{\mathrm{L}}$ use divided by DMI. 
Table 8. Effect of diet on selected milk fatty acids ( $\mathrm{g} / \mathrm{kg}$ of total fatty acids)

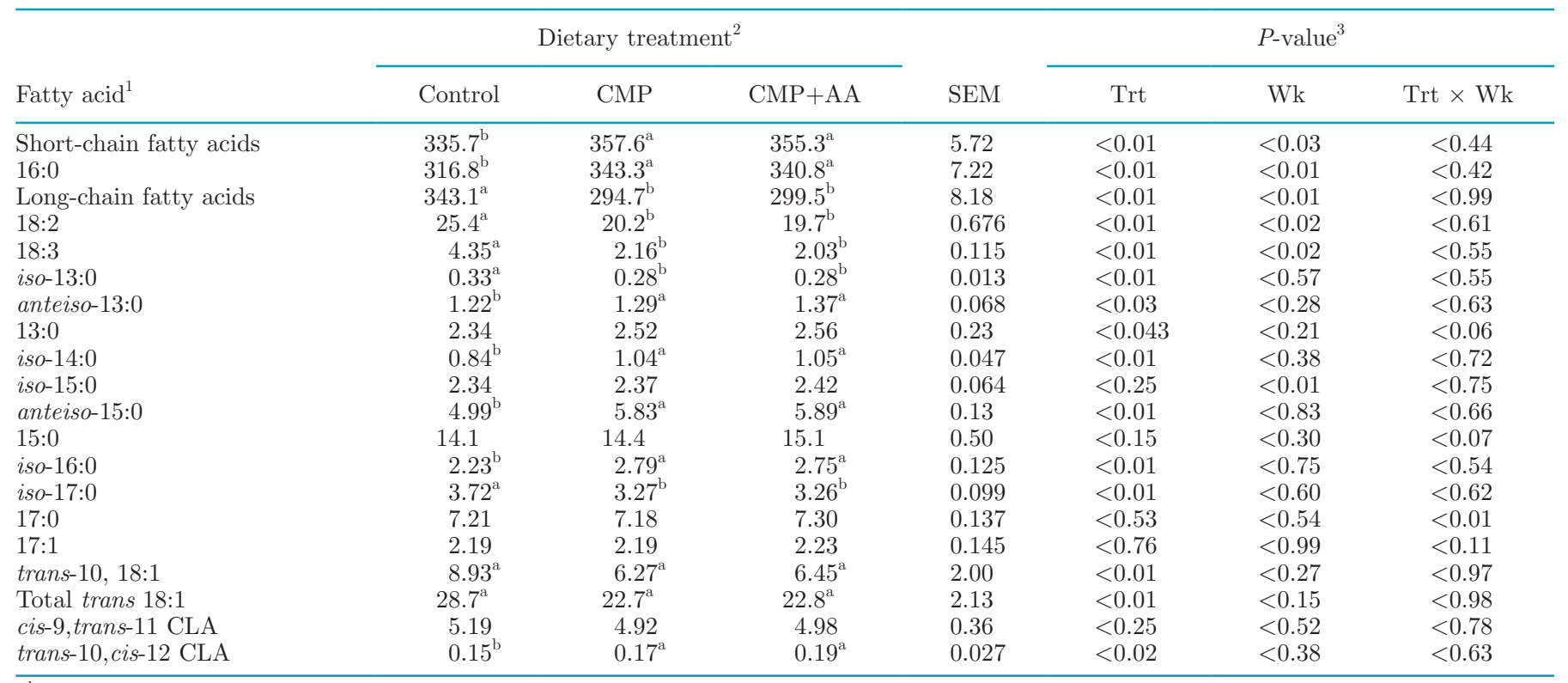

${ }_{\mathrm{a}, \mathrm{b}}$ Means in a row with unlike superscripts differ by $P$-value in far right column.

${ }^{1}$ Number of carbons:number of double bonds. Short chain fatty acids $<16 \mathrm{C}$ and long chain fatty acids $>16 \mathrm{C}$.

${ }^{2}$ Diets based on conventional ingredients (control) or corn silage and a corn milling product without (CMP) or with supplemental rumenprotected lysine and methionine $(\mathrm{CMP}+\mathrm{AA})$.

${ }^{3}$ Effect of treatment (Trt), week within period (Wk), and their interaction. Based on Slice option, Wk affected cows fed CMP+AA but not control or CMP.

changes in plasma Lys concentrations and milk protein yields were not consistent and did not follow the expected response curve (Weekes et al., 2006). The lack of an increase in plasma Lys for cows fed CMP $+\mathrm{AA}$ could mean that the product did not actually increase supply of metabolizable Lys, that the increased supply increased flux (e.g., increased use by the mammary gland), or that absorbed Lys was being used before entering the systemic circulation.

\section{Milk Fatty Acids}

No differences in milk fatty acids were observed between $\mathrm{CMP}$ and $\mathrm{CMP}+\mathrm{AA}$, but several differences occurred between cows fed those diets and cows fed the control (Table 8). Some of the differences reflect differences in dietary concentrations (Table 2) of specific fatty acids (e.g., C18:3). Cows fed control had higher $(P<0.01)$ concentrations of trans-10 $\mathrm{C} 18: 1$ and total trans fatty acids, but lower concentrations $(P<0.02)$ of trans-10,cis-12 CLA; the values were within normal ranges and agree with the lack of treatment differences in milk fat percentage. Differences in several odd- and branched-chain fatty acids were also observed and were generally in line with expected differences based of changes in dietary starch and NDF (Fievez et al., 2012).

\section{CONCLUSIONS}

A diet of corn products (corn silage and CMP) and minerals and vitamins reduced milk yield and yields of milk components compared with a more conventional diet based on multiple ingredients. The energy supplied by the 2 diets was similar, but cows fed CMP-based diets partitioned more $\mathrm{NE}_{\mathrm{L}}$ toward body reserves at the expense of milk energy output, suggesting that energy was not the limiting nutrient for milk production. Adding RP-Met and RP-Lys to the CMP diet increased milk protein yield modestly, but protein yield was still lower than for cows fed control. Multiple AA may have been limiting when all dietary protein was derived from corn products.

\section{ACKNOWLEDGMENTS}

Salary and research support was provided by state and federal funds appropriated to the Ohio Agricultural Research and Development Center, The Ohio State University, Manuscript 20-11AS. The CMP and additional financial support was provided by Cargill (Blair, NE). The AA products were provided by $\mathrm{H}$. J. Baker \& Bro. Inc. (Westport, CT) and Adisseo Inc. (Alpharetta, GA). 


\section{REFERENCES}

Appuhamy, J. A. D. R. N., J. R. Knapp, O. Becvar, J. Escobar, and M. D. Hanigan. 2011. Effects of jugular-infused lysine, methionine, and branched-chain amino acids on milk protein synthesis in highproducing dairy cows. J. Dairy Sci. 94:1952-1960.

AOAC International. 2000. Official Methods of Analysis of AOAC International. Vol. 1 and 2, 17th ed. AOAC International, Gaithersburg, MD.

Boddugari, K., R. J. Grant, R. Stock, and M. Lewis. 2001. Maximal replacement of forage and concentrate with a new wet corn milling product for lactating dairy cows. J. Dairy Sci. 84:873-884.

Cabrita, A. R. J., R. J. B. Bessa, S. P. Alves, R. J. Dewhurst, and A. J. M. Fonseca. 2007. Effects of dietary protein and starch on intake, milk production, and milk fatty acid profiles of dairy cows fed corn silage-based diets. J. Dairy Sci. 90:1429-1439.

Calsamiglia, S., and M. D. Stern. 1995. A three-step in vitro procedure for estimating intestinal digestion of protein in ruminants. J. Anim. Sci. 73:1459-1465.

Chen, Z. H., G. A. Broderick, N. D. Luchini, B. K. Sloan, and E. Devillard. 2011. Effect of feeding different sources of rumen-protected methionine on milk production and n-utilization in lactating dairy cows. J. Dairy Sci. 94:1978-1988.

Davidson, S., B. A. Hopkins, D. E. Diaz, S. M. Bolt, C. Brownie, V. Fellner, and L. W. Whitlow. 2003. Effects of amounts and degradability of dietary protein on lactation, nitrogen utilization, and excretion in early lactation Holstein cows. J. Dairy Sci. 86:16811689.

Donkin, S. S., G. A. Varga, T. F. Sweeney, and L. D. Muller. 1989. Rumen-protected methionine and lysine: Effects on animal performance, milk protein yield, and physiological measures. J. Dairy Sci. 72:1484-1491

Fekkes, D. 1996. State of the art high performance liquid chromatographic analysis of amino acids in physiological samples. J. Chromatog. B Biomed. Appl. 682:3-22.

Fellner, V., and R. L. Belyea. 1991. Maximizing gluten feed in corn silage diets for dairy cows. J. Dairy Sci. 74:996-1005.

Fievez, V., E. Colman, J. M. Castro-Montoya, I. Stefanov, and B. Vlaeminck. 2012. Milk odd- and branched-chain fatty acids as biomarkers of rumen function-an update. Anim. Feed Sci. Technol. 172:51-65

Goering, H. K., and P. J. V. Soest. 1970. Forage fiber analysis. Agriculture Hand. 379. USDA, Washington, DC.

Guinard, J., and H. Rulquin. 1994. Effects of graded amounts of duodenal infusions of lysine on the mammary uptake of major milk precursors in dairy cows. J. Dairy Sci. 77:3565-3576.

Jenkins, T. C. 2000. Feeding oleamide to lactating jersey cows 1. Effects on lactation performance and milk fatty acid composition. J. Dairy Sci. 83:332-337.

Lee, C., A. N. Hristov, T. W. Cassidy, K. S. Heyler, H. Lapierre, G. A. Varga, M. J. de Veth, R. A. Patton, and C. Parys. 2012. Rumenprotected lysine, methionine, and histidine increase milk protein yield in dairy cows fed a metabolizable protein-deficient diet. J. Dairy Sci. 95:6042-6056.

Mullins, C. R., D. Weber, E. Block, J. F. Smith, M. J. Brouk, and B. J. Bradford. 2013. Short communication: Supplementing lysine and methionine in a lactation diet containing a high concentration of wet corn gluten feed did not alter milk protein yield. J. Dairy Sci. 96:5300-5305.

NRC. 2001. Nutrient Requirements of Dairy Cattle. 7th rev. ed. ed. Natl. Acad. Press, Washington, DC.

Oba, M., and M. S. Allen. 2003. Effects of corn grain conservation method on feeding behavior and productivity of lactating dairy cows at two dietary starch concentrations. J. Dairy Sci. 86:174183.

Ordway, R. S., S. E. Boucher, N. L. Whitehouse, C. G. Schwab, and B. K. Sloan. 2009. Effects of providing two forms of supplemental methionine to periparturient Holstein dairy cows on feed intake and lactational performance. J. Dairy Sci. 92:5154-5166.

Patton, R. A. 2010. Effect of rumen-protected methionine on feed intake, milk production, true milk protein concentration, and true milk protein yield, and the factors that influence these effects: A meta-analysis. J. Dairy Sci. 93:2105-2118.

Piepenbrink, M. S., T. R. Overton, and J. H. Clark. 1996. Response of cows fed a low crude protein diet to ruminally protected methionine and lysine. J. Dairy Sci. 79:1638-1646.

Rezac, D. J., K. N. Grigsby, N. M. Bello, and B. J. Bradford. 2012. Effects of varying rates of tallgrass prairie hay and wet corn gluten feed on productivity of lactating dairy cows. J. Dairy Sci. 95:842-849

Robinson, P. H. 2010. Impacts of manipulating ration metabolizable lysine and methionine levels on the performance of lactating dairy cows: A systematic review of the literature. Livest. Sci. 127:115126.

Rulquin, H., and L. Delaby. 1997. Effects of the energy balance of dairy cows on lactational responses to rumen-protected methioninethe energy. J. Dairy Sci. 80:2513-2522.

SAS Institute. I. 2011. SAS/Stat 9.3 User's Guide. SAS Inst. Inc. Cary, NC.

Schroeder, J. W. 2003. Optimizing the level of wet corn gluten feed in the diet of lactating dairy cows. J. Dairy Sci. 86:844-851.

Schwab, C. G., N. L. Whitehouse, D. Luchini, and B. Sloan. 2009. Reevaluation of the breakpoint estimates for the NRC (2001) required concentrations of lysine and methionine in metabolizable protein for maximal content and yield of milk protein. J. Dairy Sci. 92(suppl. 1):103 (Abstr.).

Tyrrell, H. F., and J. T. Reid. 1965. Prediciton of the energy value of cow's milk. J. Dairy Sci. 48:1215-1223.

Vanhatalo, A., P. Huhtanen, V. Toivonen, and T. Varvikko. 1999. Response of dairy cows fed grass silage diets to abomasal infusions of histidine alone or in combinations with methionine and lysine. J. Dairy Sci. 82:2674-2685.

Varvikko, T., A. Vanhatalo, T. Jalava, and P. Huhtanen. 1999. Lactation and metabolic responses to graded abomasal doses of methionine and lysine in cows fed grass silage diets. J. Dairy Sci. $82: 2659-2673$

Vyas, D., and R. A. Erdman. 2009. Meta-analysis of milk protein yield responses to lysine and methionine supplementation. J. Dairy Sci. 92:5011-5018.

Weekes, T. L., P. H. Luimes, and J. P. Cant. 2006. Responses to amino acid imbalances and deficiencies in lactating dairy cows. J. Dairy Sci. 89:2177-2187.

Weiss, W. P. 2012. Use of a corn milling product in diets for dairy cows to alleviate milk fat depression. J. Dairy Sci. 95:2081-2090.

Weiss, W. P., and J. M. Pinos-Rodriguez. 2009. Production responses of dairy cows when fed supplemental fat in low- and high-forage diets. J. Dairy Sci. 92:6144-6155.

Weiss, W. P., N. R. St-Pierre, and L. B. Willett. 2009. Varying type of forage, concentration of metabolizable protein, and source of carbohydrate affects nutrient digestibility and production by dairy cows. J. Dairy Sci. 92:5595-5606.

Weiss, W. P., and D. J. Wyatt. 2000. Effect of oil content and kernel processing of corn silage on digestibility and milk production by dairy cows. J. Dairy Sci. 83:351-358.

Weiss, W. P., and D. J. Wyatt. 2003. Effect of dietary fat and vitamin e on alpha-tocopherol in milk from dairy cows. J. Dairy Sci 86:3582-3591.

Wildman, E. E., G. M. Jones, P. E. Wagner, R. L. Boman, J. H. F Troutt, and T. N. Lesch. 1982. A dairy cow body condition scoring system and its relationship to standard production characteristics. J. Dairy Sci. 65:495-501. 